\title{
Rapid Assessment of Water Quality in Teluk Lake by Using Macroinvertebrates (A Family Level Biotic Index)
}

\author{
Siswanta Kaban ${ }^{1,2}$, M. Edi Armanto ${ }^{3}$, M. Rasyid Ridho ${ }^{4}$, and Poedji L. Hariani ${ }^{4}$ \\ ${ }^{1}$ Research Institute for Inland Fisheries and Extension, Palembang, Indonesia \\ ${ }^{2}$ Doctoral Sudent of Environmental Science Program, Universitas Sriwijaya, \\ Palembang, Indonesia \\ ${ }^{3}$ Faculty of Agriculture, Universitas Sriwijaya, Indralaya Sumatera Selatan, \\ Indonesia \\ ${ }^{4}$ Faculty of Mathematics and Natural Sciences, Universitas Sriwijaya, Indralaya \\ Sumatera Selatan, Indonesia
}

\begin{abstract}
In this study the water quality of Teluk Lake, Jambi Province by biological indices using macroobenthic during December 2017 to March 2018 were evaluated. Macro obenthic have been the most commonly indicator of running water quality to rapidly detect water quality changes. The methodology consisted on three stages: 1) macro invertebrates sampling and and sorting of the organisms in laboratory, 2) taxonomic identification of organisms and 3) determination and scoring with the Biological Monitoring Working Party -Average Score per Taxon (BMWP-ASPT) index. Result of water quality of Teluk Lake based on the diversity of macroinvertebrates was degraded with BMWP-ASPT index below 4. Based on the BMWP-ASPT score of the macroinvertebrates, both of sampling 1 and 2 were polluted with the category of medium and heavily polluted. In general, the decreasing of water quality of Teluk Lake was due to anthropogenic activities, so that the intolerant macro invertebrates could not survive in polluted waters while the tolerant ones can adapt well to the polluted aquatic environment.
\end{abstract}

\section{Introduction}

Teluk Lake is a flood plain lakes where located in the city of Jambi, Its will be flooded by the river flow and even connected with the Batanghari River. In fact, around the lake people use for domestic activities, agriculture and fish farming. The rapid development of civilizations in recent decades has led to increased human impact on the natural environment [1]. [2] says that the anthropogenic activities have a strong effect on aquatic ecosystems, especially in biotic communities and ecological functions. According to [3] river flow into the lake will get organic material so it can change the composition of nutrients, minerals and substrates on the bottom of the waters and this process will affect to the ecosystem changes. In the water, if ecosytems was degraded will be changes of aquatic 
organisms such as fish, plankton and benthic community. According to[4] in aquatic ecosystems, benthic communities are particularly important in lakes and rivers. Research on aquatic organism can be used to know the environmental changes caused by anthropogenic case[5]

Benthic plays an important role in life in the waters this is because benthic has a role in nutrient cycles in the bottom waters, demersal fish food, so it is very useful for demersal fisheries, and benthic communities in shallow waters are widely used as the main tool to evaluate the pollution of an environment, because the life of benthos is closely related to the bottom of the waters. Macrozoobenthic are often used in assessing the environmental quality of waters [6] . Macrozoobenthic are organisms that are often used as pollution indicators [7] and play a role in the biomonitoring of aquatic $[4,8]$. According to $[9,10]$ that benthic biota is a living biota that settled in sediment, so it can be used as a good indicator. says that benthic could be retains on both of soft and hard substrate and has sensitivity to some contaminants, low mobility [4].

Generally chemico-physical measurements and biological monitoring or bio monitoring are used for determining the level of environmental pollution. The most direct approach to reveal pollution is chemical analysis such as water or sediment. It cannot afford powerful evidence on integrated influence and possible toxicity of pollution on organisms and ecosystem. Indeed they will be searched by biological monitoring. Bio monitoring is now recognized as one of the most valuable tools available in the arsenal of environmentalists. It gives indication of past and current status like a videotape whereas chemico-physical analysis reflects existing conditions when sample taken like snapshots[11, 12] .

[13] inform that numerous advantages of using macroinvertebrates for bio monitoring, such as they are large in size and therefore relatively easy to see with the naked eye. Importantly, keys are available for identifying the organisms at the family level. Benthic macroinvertebrates possess limited mobility, making them easy to collect and collection can be done with the use of inexpensive equipment. [14] determination of macroo zoo benthic is very important to know the aquatic indices but it takes funds, experts and knowledge about fauna.

Teluk Lake is a oxbow lake type, the bottom of the lake converges with the Batanghari river flow. Teluk Teluk is Flood Plain Lake in located in Danau Teluk District, Jambi City District with altitude 16-23 m above sea level and total area around 40-60 Ha. In general, the community around of water dump waste directly into the river, besides that there are also washing, fish cultivation and agriculture could be impact on water quality and aquatic organism. So the research will be done by determining the biotic index, it will be used as a reference to know the level of tolerance of each organism. If low tolerant organisms are more tolerant to pollution, whereas highly tolerant organisms are more intolerant[15]. The biotic index used in this study is by combining the BMWP-ASPT index (Biological Monitoring Work Party-Average Score Per Taxon).

\section{Materials and Methods}

This research was conducted in Teluk Lake, Jambi Province. The Teluk Lake located in Kelurahan Ulu Gedong, Teluk District (Figure 1). Sampling was conducted in December 2017 to March 2018. 


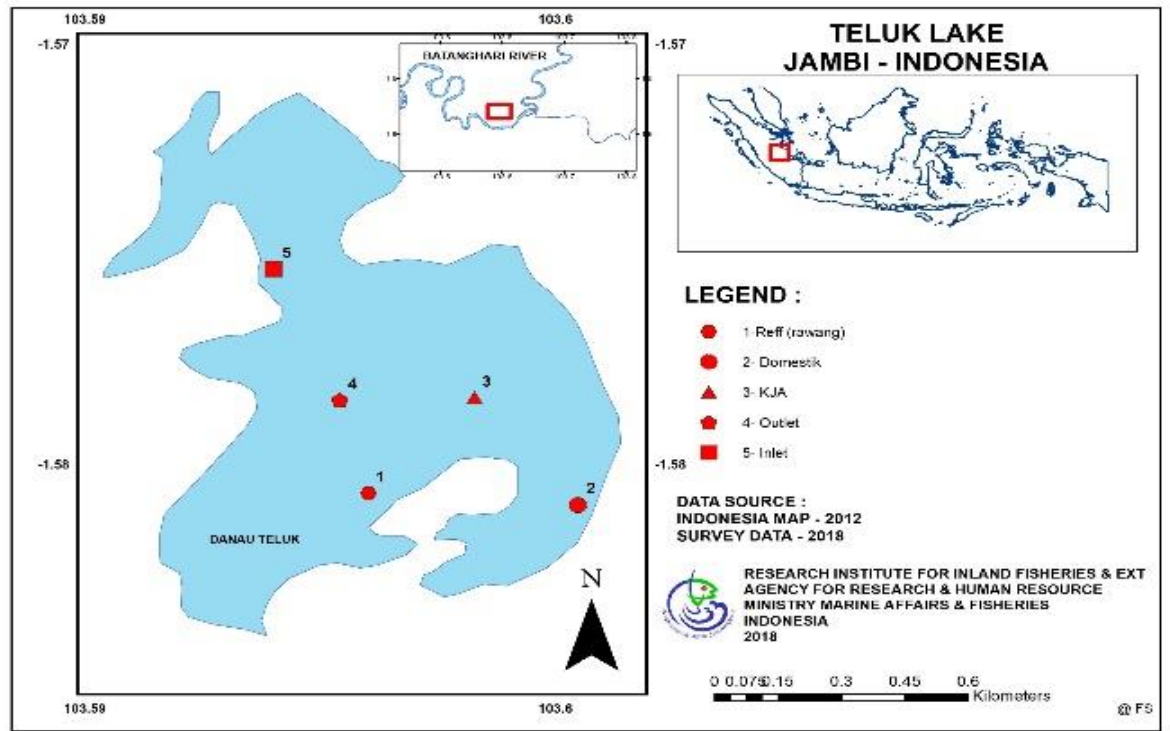

Fig. 1. Sampling site in Teluk Lake

Sampling was conducted in 5 sampling sites based on purposive sampling method, there are 5 location was analysed of benthic to detect of water quality:

1. ST I (Reference site) is an area where there are plant crops and quite far from the population activity.

2. ST II (Domestic site) is an area close to local population and waste activity

3. ST III (Cages site) is an area close to fish farming activities (net floating cages)

4. ST IV (Outlet site) is the outflow area of the lake, the area where the water outflows into the lake

5. ST V (Inlet site) is an inlet water flow area, the area where the water flows into the lake

Macroinvertebrate analysis has been used by Scoring Biological Monitoring Working Party-Average Score per taxon (BMWP-ASPT). To determine the scores of biological data determined by determining the ASPT value, the data is analyzed by using the BMWP index method. The steps of determining the BMWP index are as follows

1. Classified data and matched to the BMWP table and scores the families of each station

2. Summing up the scores obtained from each macrozoobentos family

3. Determined the BMWP-ASPT Index by dividing the value of BMWP by the number of families

Value of ASPT $=\mathrm{A} / \mathrm{B}$

Where: $A=$ Total of BMWP Index

$\mathrm{B}=$ Number of Families

There are some of value BMWP, we can summing up it with classified on BMWP showed in Table 1. 
Tabel 1. BMWP ASPT Interpretation Score Table

\begin{tabular}{|c|c|}
\hline Family & Score \\
\hline 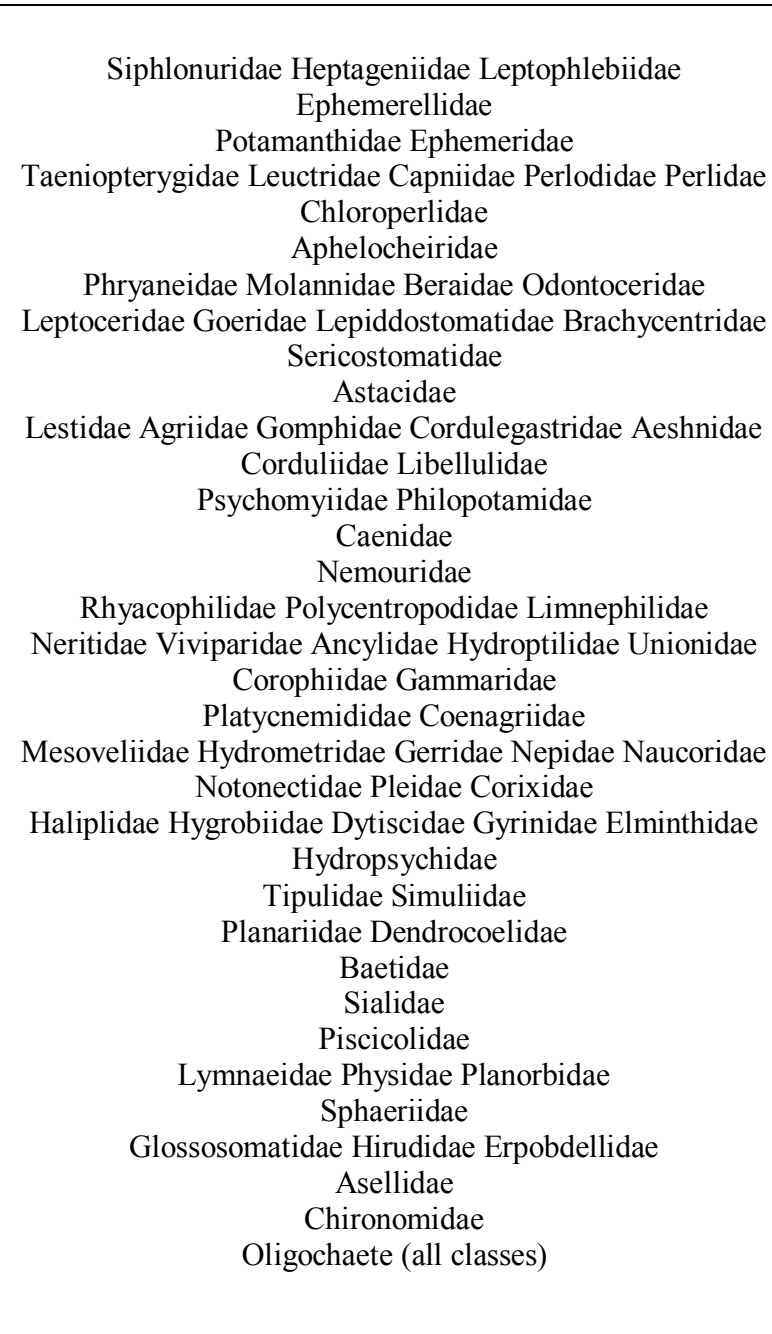 & $\begin{array}{l}3 \\
2 \\
1\end{array}$ \\
\hline
\end{tabular}

To knowing and interpretation of benthic index showed in Table 2:

Table 2. Value of Water Quality using BMWP-ASPT index

\begin{tabular}{|c|c|}
\hline Value of BMWP-ASPT & Status \\
\hline $1-4$ & Heavy Polluted \\
\hline $5-7$ & Moderate \\
\hline $8-10$ & Clean Water \\
\hline
\end{tabular}




\section{Results and Discussions}

The results of a study show that found 12 genera of 4 sub-classes dominated by oligocaeta in 2017 (Table 2). In general, the family of oligochaete illustrates that the environment has been subjected to pressure caused by pollution. If we viewed from the BMWP table, oligochaete is an environmental indicator that is tolerant to pollutants.

Table 3. Macroinvertebrates in Teluk Lake, 2017

\begin{tabular}{|c|c|c|c|c|c|c|c|c|c|}
\hline No & Class & Family & Species & $\begin{array}{c}\text { ST } \\
\mathbf{1}\end{array}$ & $\begin{array}{c}\text { ST } \\
\mathbf{2}\end{array}$ & $\begin{array}{c}\text { ST } \\
\mathbf{3}\end{array}$ & $\begin{array}{c}\text { ST } \\
\mathbf{4}\end{array}$ & $\begin{array}{c}\text { ST } \\
\mathbf{5}\end{array}$ & $\mathbf{N}$ \\
\hline 1 & Diptera & $\begin{array}{c}\text { Tanypodina } \\
\text { e }\end{array}$ & Tanypus sp & $\sqrt{ }$ & $\sqrt{ }$ & $\sqrt{ }$ & $\sqrt{ }$ & $\sqrt{ }$ & 78 \\
\hline 2 & & Naididae & Stephensoniana & & $\sqrt{ }$ & & & & 1 \\
\hline 3 & & & Stylaria sp & & & & & $\sqrt{ }$ & 1 \\
\hline 4 & Oligochaete & Tubificidae & Aulodrilus sp & $\sqrt{ }$ & $\sqrt{ }$ & $\sqrt{ }$ & & $\sqrt{ }$ & $\begin{array}{c}12 \\
9\end{array}$ \\
\hline 5 & & & Branchiura sowerbyi & $\sqrt{ }$ & $\sqrt{ }$ & $\sqrt{ }$ & & & 64 \\
\hline 6 & & $\begin{array}{c}\text { Immature tubificids } \\
\text { with hair setae }\end{array}$ & & $\sqrt{ }$ & $\sqrt{ }$ & & $\sqrt{ }$ & 15 \\
\hline 7 & & $\begin{array}{c}\text { Immature tubificids } \\
\text { without hair setae }\end{array}$ & & & $\sqrt{ }$ & & & 1 \\
\hline 8 & Gastropod & Viviparidae & Bellamya sumatrensis & $\sqrt{ }$ & $\sqrt{ }$ & $\sqrt{ }$ & & & 5 \\
\hline 9 & & $\begin{array}{c}\text { Ampullariid } \\
\text { a }\end{array}$ & Pomacea canaliculata & $\sqrt{ }$ & & & & & 3 \\
\hline 10 & & Thiaridae & Brotia sp & $\sqrt{ }$ & & & & & 3 \\
\hline 11 & Bivalve & Unionidae & Anodonta sp & $\sqrt{ }$ & & & & & 3 \\
\hline 12 & & & $\begin{array}{c}\text { Margaritifera } \\
\text { margaritifera }\end{array}$ & $\sqrt{ }$ & & & & & 8 \\
\hline
\end{tabular}

Notes: $\sqrt{ }=$ Family of makrooinvertebrates

$\mathrm{N}=$ Abundance of Species

Based on calculation of the value BMWP-ASPT index on 2017, it ranged from 1.7 to 4.5. The lowest index value at station 5 with a BWMP index of 1.7 , there is a domestic location close to the activity of the population. It will cause the incoming waste of the population and influence to water pollution. The highest index value of BMWP obtained in station 5 with the value of the index of BMWP 4.5, there is a location far from the influence of human activity and many plants and plants around this location (Figure.2). 


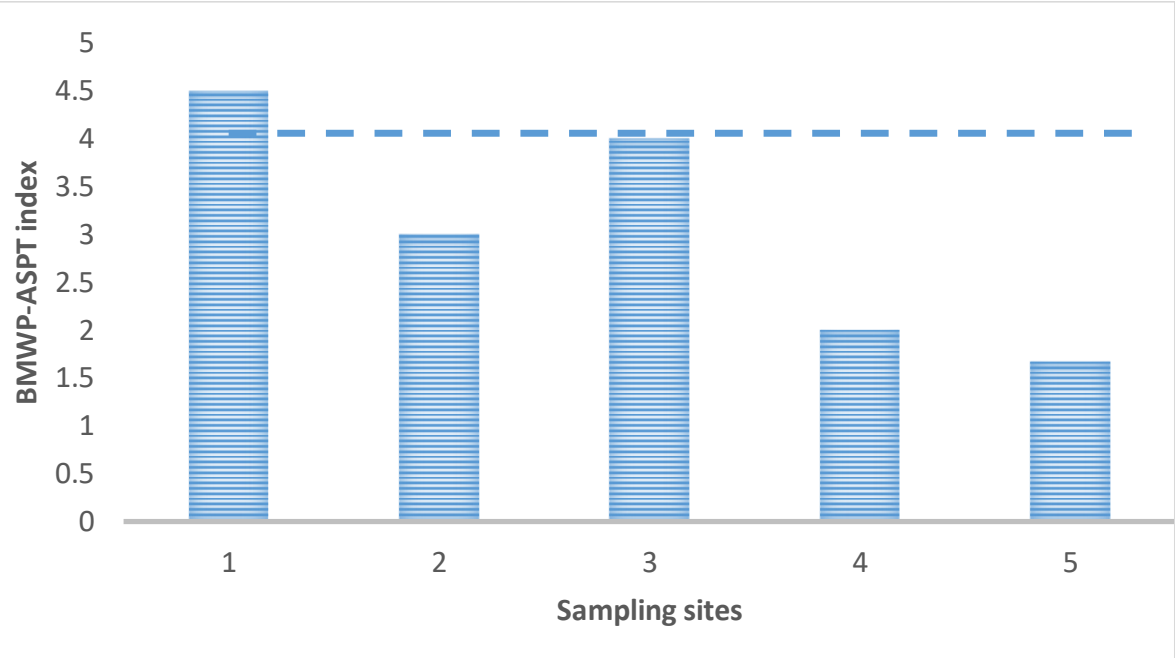

Fig. 2. Value of BWMP-ASPT index in Teluk Lake, 2017

Based on the results of research conducted in 2018, the macroinvertebrates found in the Teluk Lake consists of 7 families and covered in 3 classes namely oligochaete consists of genus Aulodrilus, Immature wedot,, Immature with hair saeta, Branchiura sowerbyi, Nais and Dero (Table 4). The condition illustrates that the existing of macrooinvertebrate conditions are dominant and it show that the water was polluted.

Table 4. Macroinvertebrates in Teluk Lake, 2018

\begin{tabular}{|c|c|c|c|c|c|c|c|c|c|}
\hline No & Class & Family & Genus & ST 1 & ST2 & ST3 & ST4 & ST5 & $\mathbf{N}$ \\
\hline 1 & $\begin{array}{l}\text { Oiligocha } \\
\text { eta }\end{array}$ & Tubificidae & Aulodrilus sp & $\sqrt{ }$ & $\sqrt{ }$ & $\sqrt{ }$ & & $\sqrt{ }$ & 4 \\
\hline 2 & & & Immature wedot & $\sqrt{ }$ & $\sqrt{ }$ & & & & 2 \\
\hline 3 & & & $\begin{array}{l}\text { Immature } \\
\text { tubificids with } \\
\text { hair setae }\end{array}$ & $\sqrt{ }$ & $\sqrt{ }$ & $\sqrt{ }$ & & & 3 \\
\hline 4 & & & $\begin{array}{l}\text { Branchiura } \\
\text { sowerbyi }\end{array}$ & $\sqrt{ }$ & $\sqrt{ }$ & $\sqrt{ }$ & & & 3 \\
\hline 5 & Diptera & Naididae & Nais sp & $\sqrt{ }$ & $\sqrt{ }$ & & & & 8 \\
\hline 6 & & & Dero sp & $\sqrt{ }$ & $\sqrt{ }$ & $\sqrt{ }$ & & & $\begin{array}{l}1 \\
2\end{array}$ \\
\hline 7 & & $\begin{array}{l}\text { Chaoborida } \\
\text { e }\end{array}$ & Chaobarus sp & & $\sqrt{ }$ & $\sqrt{ }$ & $\sqrt{ }$ & $\sqrt{ }$ & $\begin{array}{l}1 \\
6\end{array}$ \\
\hline 8 & & $\begin{array}{l}\text { Tanypodina } \\
\mathrm{e}\end{array}$ & Tanypus sp & & $\sqrt{ }$ & $\sqrt{ }$ & $\sqrt{ }$ & & 6 \\
\hline 9 & Gastropod & Viviparidae & $\begin{array}{l}\text { Bellamya } \\
\text { sumatrensis }\end{array}$ & $\sqrt{ }$ & $\sqrt{ }$ & & $\sqrt{ }$ & $\sqrt{ }$ & $\begin{array}{l}1 \\
2 \\
\end{array}$ \\
\hline
\end{tabular}

Notes: $\sqrt{ }=$ Family of makrooinvertebrates

$\mathrm{N}=$ Abundance of Species 
The value of the index of BMWP-ASPT calculation 0n 2018, It's ranged from 2.25 to 6. The lowest index value on the station 3 with the value of BWMP index is 2.25 , there is a location close to activity of the population. So it will make to environmental pressure from anthropogenic influence. The highest index value of BMWP in get at station 1 with the value of index BMWP is 6 (Figure.3).

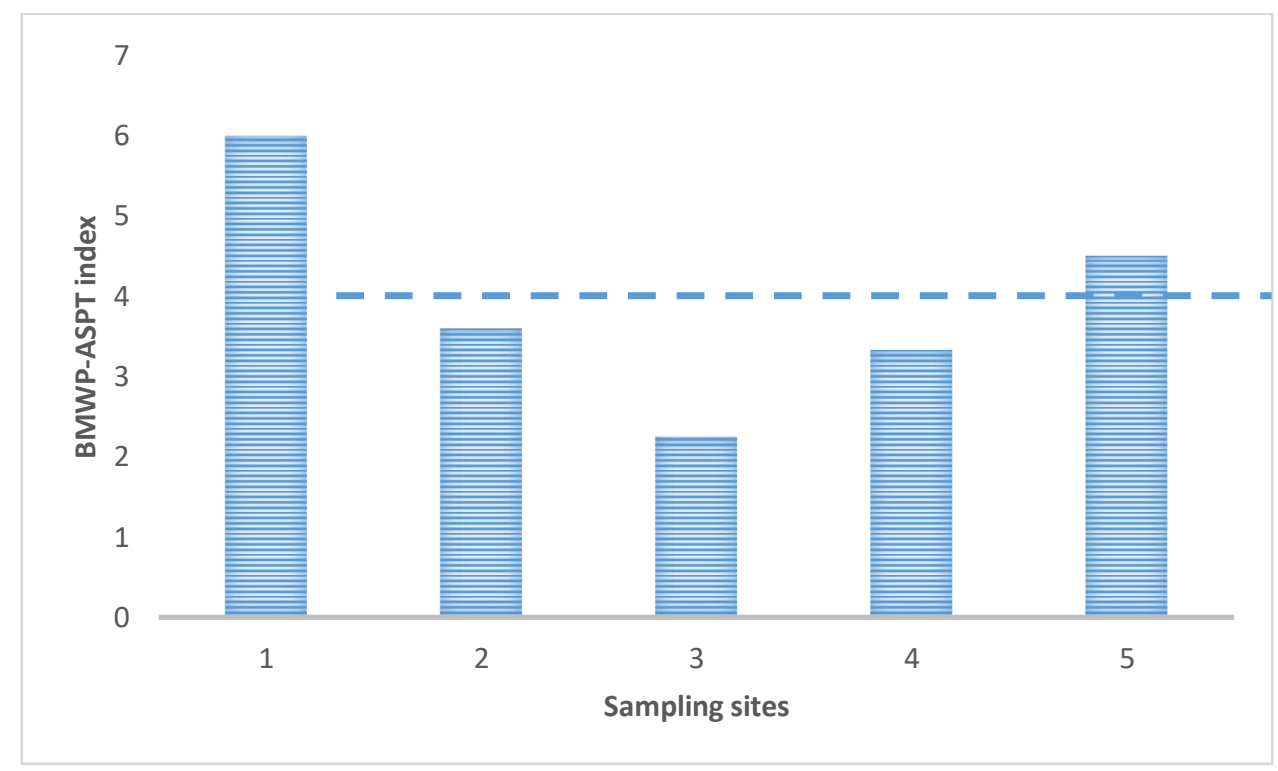

Fig. 3. Value of BWMP-ASPT index in Teluk Lake, 2018

Overall, assessment of water quality in the Teluk Lake using macroinvertebrates indicator has been subjected to environmental stresses where caused by the influence of anthropogenic waste, especially the waste of the population directly into the waters and the residual feed of fish dissolved to the bottom of the waters.

The value of BWMP-ASPT index on 2017 and 2018 in Teluk Lake is under 4, it shown that water quality was degraded. Diversity of gastropods and bivalve could be using to predicting clean water, in this research both of them was decreasing. In fact, bivalve didn't found in 2018, it shown that pollution will be affect to survival of aquatic organism especially benthic organism.

\section{Conclusion}

The conclusion of this research, determining water quality through the BMWP-ASPT method as a biotic index by using macroinvertebrates in Teluk Lake was moderate polluted. Macroinvertebrates founded along Teluk Lake of twelve different families: Tubificidae, Naididae, Tanypodinae, Viviparidae, Ampullariida, Thiaridae, Unionidae dan Chaoboridae. 


\section{References}

1. Stryjecki R. The Impact of Human Activity on the Water Mite Fauna (Acari, Hydrachnidia) of the "LasyJanowskie" Landscape Park (South-Eastern Poland). Proceedings of the IV Symposium oleh Europian Association of Acarologist. Kluwer Academic Publisher (2002)

2. Maddock I. Freshwater Biology 41, 2 (1999)

3. Tjahjo dan PurnamaningtyasLimnotek 17, 2 (2010)

4. Sharma R. Kumar A, Vyas V. Intl J Adv Fish Aquat Sci 1, 1 (2013)

5. Chessman B. Australian Journal of Ecology 20, 1 (1995)

6. Vyas V, Bhawsar A. Intl J Environ Biol 3, 2 (2013)

7. Minggawati I. Ilmu Hewani Tropika 2, 2 (2013)

8. Roy S, Gupta A. Biol Environ Sci 5, 1 (2010)

9. Trisnawaty FN, Emiyarti, Afu LOA. 3, 1 (2013)

10. Purnami AT, Sunarto, Setyono P. Ekosains 2, 2 (2010)

11. Mandaville SM. Benthic macroinvertebrates in freshwaters-taxa tolerance values, metrics, and protocols. (Soil and Water Conservation Society of Metro Halifax, Project H-1, 2002)

12. Muralidharan M, Selvakumar C, Sundar S, Raja M. Indian Journal of Biotechnology $1(2010)$

13. Resh, V.H. Myers, M.J. Hannaford M.J. Macroinvertebrates as biotic indicators of environmental quality (In: F.R. Hauer, G.A Lamberti (ed), Stream ecology, Academic Press, California, 1996)

14. Deemool, M and Prommi, O.T. Int. J. Pharm. Res. Allied Sci 6, 1 (2017)

15. Rahman, A.K.N. Biodidaktika 12, 1 (2017) 